\title{
Modeling Conductive Heat Flow Between Steep Rock Walls and Talus Slopes - Thermal Processes and Geomorphological Implications
}

\author{
Kristin Sæterdal Myhra*, Sebastian Westermann and Bernd Etzelmüller \\ Department of Geosciences, University of Oslo, Oslo, Norway
}

OPEN ACCESS

Edited by:

Christian Hauck

Université de Fribourg, Switzerland

Reviewed by:

Henning Löwe,

WSL Institute for Snow and Avalanche

Research SLF, Switzerland

Alan Rempel,

University of Oregon, United States

Martin Scherler.

Université de Fribourg, Switzerland

Jonas Wicky,

Université de Fribourg, Switzerland,

in collaboration with reviewer MS

*Correspondence:

Kristin Sæterdal Myhra

k.s.myhra@hvl.no

Specialty section:

This article was submitted to

Cryospheric Sciences,

a section of the journal

Frontiers in Earth Science

Received: 21 January 2019

Accepted: 08 July 2019

Published: 07 August 2019

Citation:

Myhra KS, Westermann S and

Etzelmüller B (2019) Modeling

Conductive Heat Flow Between Steep

Rock Walls and Talus Slopes -

Thermal Processes

and Geomorphological Implications.

Front. Earth Sci. 7:192.

doi: 10.3389/feart.2019.00192
The thermal regime in steep and snow-free rock slopes is crucial for understanding rock slope stability, frost weathering and the associated material production in steep mountain areas. In this study, we model heat flow and explore the hypothesis that strong thermal gradients are maintained in transition areas between snow-free rock walls and snow-covered talus slopes. The results of our 2D heat transfer modeling experiments indicate that, under the assumption of snow-free steep rock walls, conductive heat flow can cool the upper parts of an adjacent talus slope with low conductivity and induce strong thermal gradients in the solid bedrock. The modeled conductive cooling effect may be relevant for both frost weathering processes and subsequent geomorphological implications and for the thermal regime of complex surface material in rock wall-talus systems in alpine areas.

Keywords: numerical modeling, steep rock walls, talus slopes, thermal gradients, frost weathering

\section{INTRODUCTION}

Steep rock walls are spectacular, but common features in mountain regions associated with environments related to glaciations (U-shaped valley sides, cirque walls), tectonic processes or river incisions (canyons) (e.g., Steiger et al., 2016). Climatic processes determine the rock wall thermal regime, which in turn influences weathering processes that decrease the rock wall stability and give rise to source areas for rock falls and rock avalanches (e.g., Gruber and Haeberli, 2007; Krautblatter et al., 2013).

Progress has been made with predictions of the existence and temporal evolution of frozen ground in steep topography (Noetzli and Gruber, 2009; Hasler et al., 2015; Magnin et al., 2015). In addition, rock walls are areas with extensive heat loss during winter due to cooling effects caused by both low snow cover (Myhra et al., 2017) and fractures (e.g., Hasler et al., 2011). Finally, the cooling of the rock walls may influence the thermal regime in neighboring areas as demonstrated in Myhra et al. (2017). As a precondition for rock slope instabilities in steep terrain, frost weathering and bedrock weakening are important processes (Hasler et al., 2012; Krautblatter et al., 2012). These processes have been extensively investigated in the field (Matsuoka, 2008), in the laboratory (Murton et al., 2006) and through numerical modeling (Hales and Roering, 2007). It has been 
recognized that thermal gradients are important for ice segregation and subsequent frost generated crack growth (Walder and Hallet, 1985; Hallet et al., 1991). The first modeling study of frost cracking in relation to climatic parameters was performed by Anderson (1998), who investigated frost-cracking intensity (FCI) as a function of the time spent in the frostcracking window $\left(-8\right.$ to $\left.-3^{\circ} \mathrm{C}\right)$, which is the temperature interval in which the growth of segregation ice is largest. Later, Hales and Roering (2007) predicted the depth and intensity of segregation ice growth in rocks through a heat flow modeling experiment. These studies are highly valuable for evaluations regarding the effect of frost on rock fracturing, but do not account for other controlling variables of rock fracturing, e.g., rock strength.

Rock fall and rock avalanches from steep rock walls typically accumulate below their source areas. In rock walls associated with e.g., cirque glaciers, the material is incorporated into the glacier and effectively removed. Falling on land, talus accumulations are formed that provide transitions between steep and less steep terrain. Ice-supersaturation in talus accumulations can trigger creep processes and turn the landform into rock glaciers (Haeberli et al., 2006). While conductive heat transport dominates in massive rock walls, the thermal behavior of blocky surface layers is partly controlled by convective heat flow (e.g., Wicky and Hauck, 2017). The importance of convective heat transport and in particular the chimney effect in talus slopes is highlighted by both field studies and through numerical studies (e.g., Scherler et al., 2014; Wicky and Hauck, 2017). These studies indicate that the seasonally dependent chimneyeffect type of heat circulation may induce large temperature differences between the upper and the lower parts of talus slopes, with a cooling effect in the lower part. Though it is clear that convective heat flow is highly important for the ground thermal regime in coarse material, the deviation between modeled and measured components (e.g., Scherler et al., 2014) indicate that important processes are left out in the modeling experiments. Conductive heat flow driven by thermal gradients is the governing heat flow process in the solid bedrock that underlays the coarse talus material, and probably in the transition between talus and surrounding areas. Thus, temperature conditions in talus slopes are likely to be determined by the combined effect of the important air flow driven convective processes and heat conduction (Haeberli et al., 2006; Scherler et al., 2014).

In this study, we model conductive heat flow between solid rock walls and nearby talus slopes with the aim to provide a better understanding of the influence of heat flow in nearby solid bedrock on the thermal regime of talus slopes. In our previous paper (Myhra et al., 2017) we modeled conductive heat flow in a solid rock wall, where thermal conductivity is the same and the summer/winter asymmetry in heat flow origins due to snow variations. For this study, the key point is not the origin of the conductive cooling effect, but we test the hypothesis that it may influence low-conductivity landforms nearby. We use a transient 2D heat conduction model (CryoGrid2D) to investigate the heat flow and discuss geomorphological implications in view of frost weathering processes and landscape development in cold environments.

\section{MATERIALS AND METHODS}

While this is a conceptualized study, we use actual field settings to set up the numerical simulations. We benefit from published material and include parameters that are directly measured or estimated through field studies in high mountain environments.

\section{Simulation Set Up}

We modeled heat flow in steep rock walls for conditions found in high elevation mountain areas in Norway (Figure 1A). In many mountain areas in Norway, the topography has developed through multiple glaciations and is often dominated by steep slopes and gentle mountain plateaus (Etzelmüller et al., 2007). Some of the steep rock walls are found along elongated mountain ridges (Figure 1A), in a topographic setting including gentle talus slopes $\left(<35^{\circ}\right)$ and an apex above which the talus slope turns into a steep rock wall. At the top of the rock wall, the steep slope borders a flat plateau in another apex, which is a typical feature for landscapes found in Norway (Etzelmüller et al., 2007) and Iceland (Farbrot et al., 2007), and can be found along passive margins like in Greenland (Japsen et al., 2006). While steep rock walls are prone to thin and laterally variable snow conditions (Gruber and Haeberli, 2007), significant snow cover may accumulate along flat plateaus and gentle slopes. Thus, our chosen topographical setting gives rise to large spatial variations in snow cover conditions that strongly influence ground heat flow and temperature conditions.

We have modeled heat flow between steep rock slopes $\left(80^{\circ}\right)$ and more gentle talus slopes $\left(35^{\circ}\right)$ situated at elevations from 1600-2000 m asl., corresponding to elevations where Lilleøren and Etzelmüller (2011) previously mapped intact icecored moraines and rock glaciers in high mountain areas in southern Norway. We forced the model with weekly temperature data derived from conditions at the Juvvasshøe permafrost observatory $\left(61^{\circ} 40^{\prime} 32^{\prime \prime} \mathrm{N}, 08^{\circ} 22^{\prime} 04^{\prime \prime} \mathrm{E}\right.$ ) (Sollid et al., 2000; Isaksen et al., 2001, 2003; Farbrot et al., 2011) situated at $1894 \mathrm{~m}$ asl. in the Jotunheimen mountain range in southern Norway, which comprises many of the highest peaks in Norway. Borehole measurements (10-130 m deep) at elevations from 1300 to nearly $1900 \mathrm{~m}$ asl. indicate conditions from seasonal frost to continuous permafrost, and the lower limit of permafrost in a north-east exposed slope from Juvvasshøe is measured at about $1450 \mathrm{~m}$ asl. (Farbrot et al., 2011).

For the internal structure of the modeled talus slope, we implemented ground composition in accordance with field studies of talus slopes in alpine periglacial environments (Sass, 2006; Scapozza et al., 2011), complemented by field measurements from rock glaciers (Haeberli et al., 2006).

\section{The Numerical Model and Simulation Details}

\section{Heat Transfer Model}

CryoGrid 2D (Myhra et al., 2017) is a transient heat transfer model with material and temperature dependent thermal parameters including the latent heat of freezing and melting. Heat conduction is the governing heat flow process, and the evolution 
A

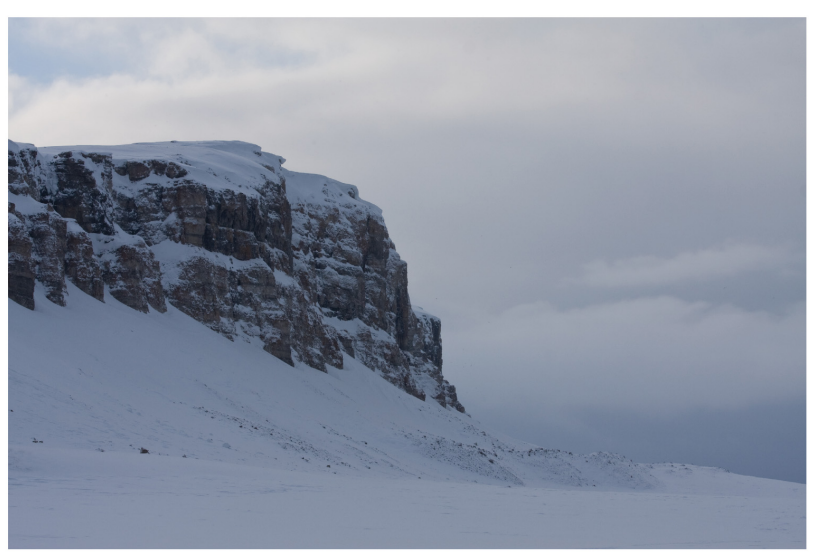

B
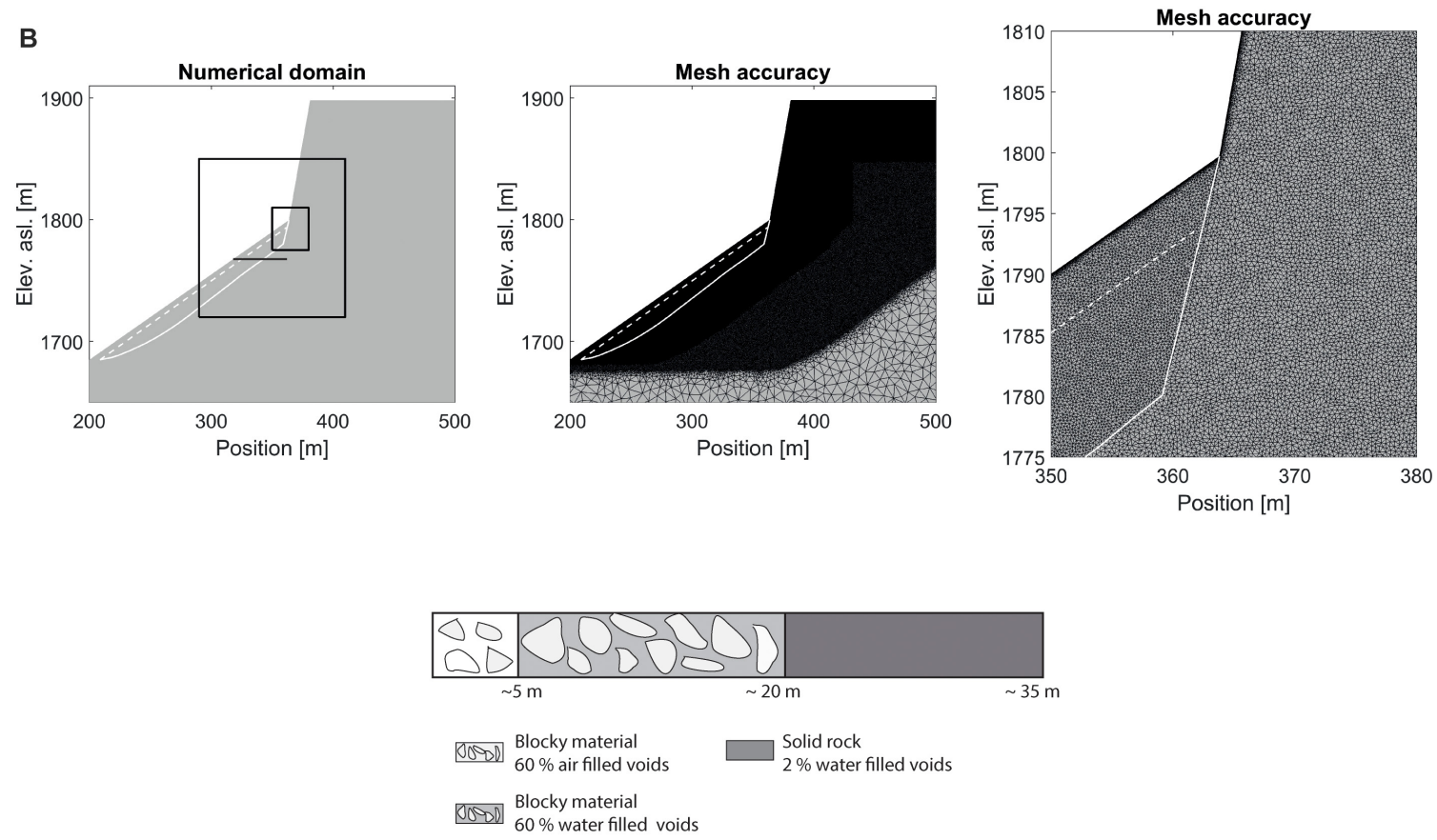

C

Boundary forcing through simulation period (Case 2)

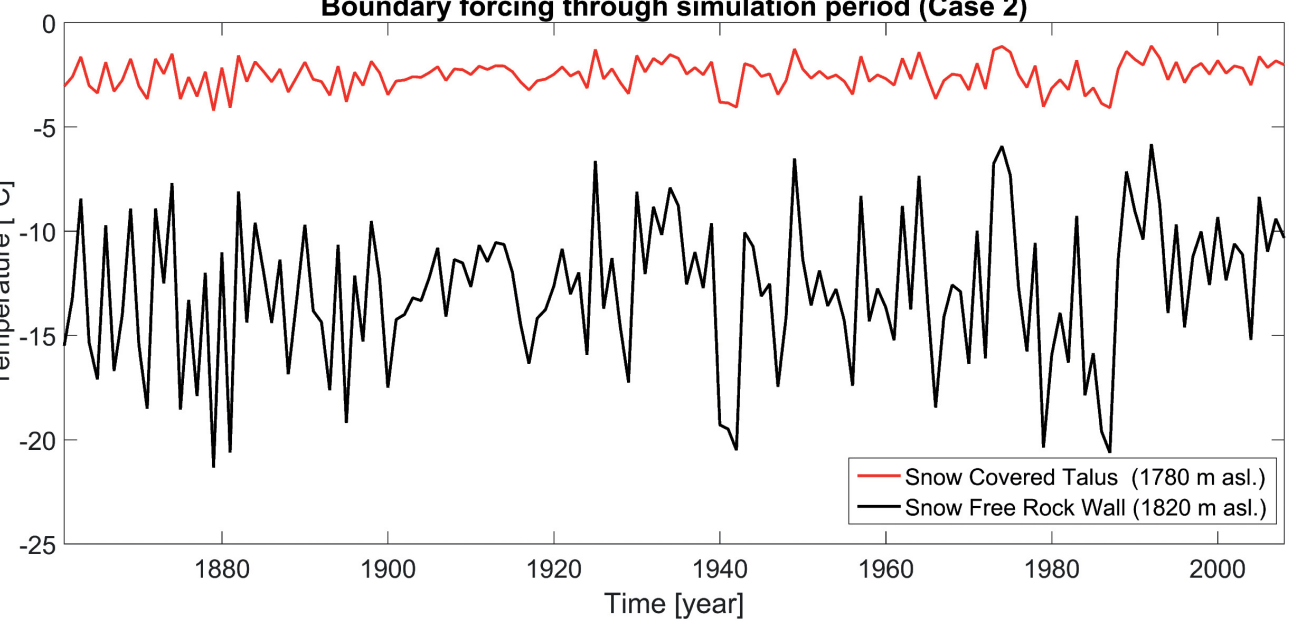

FIGURE 1 | Continued 
FIGURE 1 | (A) Talus slopes situated below steep rock walls in Hallingskarvet, southern Norway $\left(60^{\circ} 35^{\prime} 47^{\prime \prime} \mathrm{N}, 07^{\circ} 40^{\prime} 37^{\prime \prime} \mathrm{E}\right)$. (B) The numerical domain represents a vertical $2 \mathrm{D}$ cross-section through the landscape in panel (A). From top to bottom, the geometry consists of a flat plateau, a steep rock wall $\left(80^{\circ}\right)$ and a gentle talus slope $\left(35^{\circ}\right)$. The black line indicates a virtual borehole illustrating the ground components as depicted. The solid line marks the boundary between the solid bedrock (98\% mineral, $2 \%$ water) and the water-rich talus (40\% mineral, 60\% water/ice), while the dashed line marks the boundary between the water-rich talus and the blocky surface layer (40\% mineral, 2\% water, 58\% air). The square marks the area for which ground temperature fields are presented in Figures $\mathbf{2}$, 3. The mesh resolution is presented for the areas within the two squares. (C) Ground surface temperature forcing through the simulation period for one point at the snow-covered talus surface and one point at the snow-free rock wall surface. The elevation distance between the points is $40 \mathrm{~m}$.

of the ground temperature field with time, $t$, is controlled by thermal gradients, i.e., the partial derivatives of temperature with respect to space ( $x$ and $y$ ) as described by the heat conduction equation (Eq. 1). CryoGrid 2D is built on the ground thermal model CryoGrid 2 (Westermann et al., 2013) and described in detail in Myhra et al. (2017). In the following, we outline the governing equations briefly.

The heat conduction equation is given by

$$
c_{e f f} \frac{\partial T}{\partial t}=\left(\frac{\partial}{\partial x} k \frac{\partial T}{\partial x}+\frac{\partial}{\partial y} k \frac{\partial T}{\partial y}\right)
$$

where $T$ denotes temperature, $k$ the thermal conductivity and $c_{\text {eff }}$ the effective volumetric heat capacity in which the latent heat of the water-ice phase transition is included. These thermal parameters are material and temperature dependent and defined as described in Westermann et al. (2013).

To compute the thermal conductivity, we use a parametrization based on the square-root-mean of the conductivities of the ground constituents (Roy et al., 1981)

$$
k=\left(\sum_{\alpha} \theta_{\alpha} \sqrt{k_{\alpha}}\right)^{2}
$$

where $k_{\alpha}$ denotes the material-specific thermal conductivities and $\theta_{\alpha}$ denotes the volumetric contents of each of the constituents, $\alpha=$ water $(w)$, ice $(i)$, mineral $(m)$ and air $(a)$, in the system. The effective heat capacity is calculated as

$$
c_{e f f}=c(T, x, y)+L \frac{\partial \theta_{w}}{\partial T}=\sum_{\alpha} \theta_{\alpha}(T, x, y) c_{\alpha}+L \frac{\partial \theta_{w}}{\partial T}
$$

where $c_{\alpha}$ is the volumetric heat capacity, $\theta_{\alpha}$ denotes the volumetric contents of each of the constituents in the system as described previously, and $L$ is the latent heat of the water-ice phase transition. In CryoGrid 2D, the heat conduction equation (Eq. 1) is solved by the finite element method solver MILAMIN (Dabrowski et al., 2008), in which an implicit time scheme is included to account for the temporal evolution of the ground thermal regime. The system is solved on a triangular mesh (Shewchuk, 1996).

\section{Geometry and Ground Composition}

While the upper part of the numerical domain includes the slope geometry (Figure 1B), the full numerical domain reaches to $4000 \mathrm{~m}$ depth below sea level to include the effect of the geothermal heat flux. The slope geometry represents a $2 \mathrm{D}$ crosssection cutting through a talus deposit situated below a steep rock wall in an elongated mountain ridge the Norwegian mountains
(Figure 1A). We assumed translational symmetry along the third dimension, which is an acceptable first-order approximation for the topographic setting of the Norwegian landscape (see section "Simulation Set Up"). For all simulations, a triangular mesh was constructed with a depth dependent resolution (Table 1) and the simulations were run with weekly time steps over a period from the end of LIA (1868) until present. Test simulations were performed to ensure sufficient spatial resolution for simulations with weekly time step.

In detail, the geometry (Figure 1B) consists of a steep rock wall $\left(80^{\circ}\right)$ below which coarse material has accumulated and developed into a talus slope $\left(35^{\circ}\right)$, which is a common angle of repose for talus slopes (e.g., Carson, 1977). The solid bedrock was constructed with a volumetric mineral content of $98 \%$ and a volumetric water content of $2 \%$ in accordance with previous studies (Myhra et al., 2017). The talus material was constructed as a $20 \mathrm{~m}$ thick layer of blocky material in correspondence with field measurements (Morard et al., 2008; Scapozza et al., 2011) with $60 \%$ void space, which is in the range of estimates of ice content from internal structures of coarse talus deposits and rock glaciers (Haeberli et al., 2006). The upper $5 \mathrm{~m}$ was implemented as a porous layer with air filled voids as observed in the Swiss Alps (Scapozza et al., 2011) and in Norwegian mountain areas (Isaksen et al., 2001). Motivated by field observations of substantial amounts of ice in frozen talus material (Haeberli et al., 2006), we assumed fully saturated conditions in the remaining 15 m of blocky layer above the solid bedrock (Scapozza et al., 2011). In reality, we expect the ground water content to vary through the simulation period following seasonal variations such as snow melt and weather conditions, but we assume constant moisture conditions in the talus slope to avoid speculative assumptions regarding ground water conditions.

The thermal conductivities of ice $\left(k_{i}=3.5 \mathrm{~W} / \mathrm{m}^{\circ} \mathrm{C}\right)$, water $\left(k_{w}=0.57 \mathrm{~W} / \mathrm{m}^{\circ} \mathrm{C}\right)$ and air $\left(k_{a}=0.025 \mathrm{~W} / \mathrm{m}^{\circ} \mathrm{C}\right)$ were chosen following Hillel (1982). The bedrock thermal conductivity was set to $k_{m}=3.5 \mathrm{~W} / \mathrm{m}^{\circ} \mathrm{C}$ which is in the range of thermal conductivities calculated from the average mineral composition at Juvvasshøe (Isaksen et al., 2001) and consistent with typical values found for granite-rich igneous rock, such as the Norwegian

TABLE 1 | Implemented mesh accuracy.

\begin{tabular}{lc}
\hline Depth $(\mathbf{m})$ & Max. triangle size $\left(\mathbf{m}^{\mathbf{2}}\right)$ \\
\hline In Talus Slope & 0.06 \\
$0-50$ & 0.1 \\
$50-150$ & 0.5 \\
$<150$ & 50
\end{tabular}


basement rock (Clauser and Huenges, 2013). As the effective thermal conductivities are material and temperature dependent, they vary throughout the simulation and in particular across the water-ice phase transition. In the numerical model, the effective thermal conductivities are calculated for each finite element and time step. The effective thermal conductivities for the ground constituents in the solid bedrock, water-rich talus and the blocky surface for fully frozen and fully unfrozen conditions (Table 2) were calculated according to Eq. 2.

\section{Boundary Conditions}

Along the bottom of the numerical domain (4000 $\mathrm{m}$ depth bsl.), the model was forced with a constant geothermal heat flux of $50 \mathrm{~mW} / \mathrm{m}^{2}$ which is in correspondence with geothermal heat flow in the Jotunheimen areas (Pascal et al., 2010). Along vertical boundaries, at elevations below the slope geometry (Figure 1B) and along the backside of the domain, we implemented zero flux boundary conditions.

Along the slope topography and the flat plateau, we forced the model by weekly air temperature data derived from the seNorge data set operationally provided by the Norwegian Meteorological Institute (Tveito, 2000; Mohr, 2008) and the Norwegian Water and Energy Directorate (Saloranta, 2012). The seNorge data set contains daily average temperatures with a spatial resolution of $1 \mathrm{~km}$ from 1957 until present. From 1868-1956, we lack seNorge data and determined temperature series by a standardized regional method (Hanssen-Bauer and Nordli, 1998) together with seNorge air temperatures from the standard period 1961-1990, as described in Myhra et al. (2017). A thorough description of this method is found in Hanssen-Bauer and Nordli (1998). From 1957 to 2005 we implemented seNorge air temperatures directly.

Under the assumption of elevation dependent air temperatures, we constructed air temperature forcing for each node along the slopes and at the flat plateau through a linear interpolation using the mean altitudinal lapse rate of air temperature at Juvvasshøe, $0.005^{\circ} \mathrm{C} / \mathrm{m}$ (Farbrot et al., 2011). The insulating effect of a winter snow cover was implemented by temperature reduction factors ( $\mathrm{N}$-factors, $n F$ ) (Riseborough et al., 2008) for air temperatures below $0^{\circ} \mathrm{C}$ in accordance with Myhra et al. (2017). Following Figure 1A, we implemented snow along the surface of the entire talus slope and at the flat plateau. Here we used, $n F=0.2$, which corresponds to an annual mean height of snow above $0.8 \mathrm{~m}$ (Gisnås et al., 2013) along both the talus slope and the flat plateaus. We present the resulting boundary forcing through the simulation period for one point in the snow-free rock wall and one point along the snow-covered talus slope in Figure 1C. For the main simulations, we ignored snow in the rock wall caused by natural irregularities in the rock wall structure (Figure 1A), but performed a sensitivity study with mean annual snow thicknesses ranging from 0.05 to $0.25 \mathrm{~m}$

TABLE 2 | Effective thermal conductivities.

\begin{tabular}{lccc}
\hline $\begin{array}{l}\text { Effective thermal conductivity } \\
\text { (according to Eq. 2) }\end{array}$ & $\begin{array}{c}\text { Solid } \\
\text { bedrock }\end{array}$ & $\begin{array}{r}\text { Blocky } \\
\text { surface }\end{array}$ & $\begin{array}{c}\text { Water-rich } \\
\text { talus }\end{array}$ \\
\hline Fully unfrozen conditions $\left(\mathrm{W} / \mathrm{m}^{\circ} \mathrm{C}\right)$ & 3.4 & 0.73 & 1.4 \\
Fully frozen conditions $\left(\mathrm{W} / \mathrm{m}^{\circ} \mathrm{C}\right)$ & 3.5 & 0.76 & 2.7
\end{tabular}

( $n F=0.5-0.95)$ (Gisnås et al., 2013) to investigate the effect of rock wall snow accumulations. In addition, we performed control runs with $0.8 \mathrm{~m}$ snow $(n F=0.2)$ applied along the steep rock wall. Several monitoring studies of rock wall surface temperatures (Gruber et al., 2004; Hipp et al., 2014; Magnin et al., 2015, 2016) highlight especially the topographic exposition of rock walls as a modulator to rock wall surface temperatures.

Monitoring of rock wall surface temperatures in Norway (Hipp et al., 2014) indicates that high latitude solar conditions limit the influence of aspect on the surface energy budget, in particular for north facing rock walls where the surface offset is on average $1^{\circ} \mathrm{C}$. We point out that the effect of incoming solar radiation is not included in our simulation. Therefore we have run additional simulations with increased $\left(1^{\circ} \mathrm{C}\right)$ rock wall temperatures to investigate the effect of our simplified boundary conditions.

\section{Model Initialization}

Because the current ground temperature conditions are influenced by previous conditions (Noetzli and Gruber, 2009), the chosen starting point of a numerical simulation influences the modeled evolution of ground temperature conditions. At the end of the Little Ice Age (LIA) there probably were permafrost conditions at the elevations chosen for this study at Juvvasshøe (>1600 m asl.). Thus, we initialized our simulations with frozen ground conditions. To reduce the influence of the initial conditions on the result, we performed a two-step model initialization to obtain stable initial conditions. First, we calculated the average ground surface temperatures along the slopes and the top of the domain for the first 10 years of our boundary forcing data. With these average temperatures, we modeled a steady state ground temperature regime. The obtained ground temperature field was thereafter used as initial condition for a temporal simulation over the 10-year initialization period. This second step was repeated until the temperature difference between runs was on the order of $\sim 10^{-4 \circ} \mathrm{C}$. Thus, the initial temperature field for our modeling study was in equilibrium with the estimated climatic conditions at the beginning of our modeling period.

To test the effect of the initialization, we performed a sensitivity study with initial conditions shifted by $\pm 1^{\circ} \mathrm{C}$. The shift was performed before we calculated the average ground surface temperatures in the first step of the initialization procedure. The results indicate a maximum temperature deviation between the main simulation and the simulations with shifted initial conditions at the end of the simulation period of $\sim 0.4^{\circ} \mathrm{C}$ at $300 \mathrm{~m}$ depth below the talus apex. In the water-rich part of the talus slope, the extent of frozen ground changed by $\sim 1 \%$. In general, we observed a cooling effect of the rock wall on the talus slope for all simulations regardless of our choice of initial temperatures.

\section{Simulations}

We investigate the potential influence of steep and snow-free rock walls on the thermal regime of talus slopes through simulations of heat flow in the talus geometry (Figure 1B). The geometry has been shifted to different elevations from 1600 to $2000 \mathrm{~m}$ asl., corresponding to three different temperature regimes; Case 1-3 (Table 3). All other parameters than elevation above sea 
TABLE 3 | Thermal characteristics at the talus apex for Case 1-3 and Case 1-3 Control simulations.

\begin{tabular}{lcccc}
\hline & Period & Case 1 & Case 2 & Case 3 \\
\hline Elevation of talus apex $(\mathrm{m}$ asl.) & & 1700 & 1800 & 1900 \\
Average air temperature at apex $\left({ }^{\circ} \mathrm{C}\right)$ & $1881-1885$ & -5.8 & -6.2 & -6.8 \\
& $2001-2005$ & -3.7 & -4.2 & -4.7 \\
\hline
\end{tabular}

level, and thus different rock wall surface temperatures, were identical for the three cases. We present the results of six numerical simulations referred to as Case 1-3 and Case 1-3 Control. All conditions, except rock wall surface temperatures, were identical for these two simulation sets. While Case 1-3 represents the snow-free rock wall conditions that we aim to investigate, the Control simulations were performed with snowcovered rock walls to serve as a basis for comparison. In addition, we performed a sensitivity study with snow-covered steep rock walls to investigate the effect of snow accumulation in steep rock walls.

\section{RESULTS}

\section{Modeled Ground Thermal Regime in Talus Slopes}

First, we compare the modeled ground temperature evolution during the simulation period for the intermediate temperature scenario, Case 2 (Figures 2A,B), with the respective control run (Figures 2C,D) by means of average ground temperatures calculated over 5-year periods. For both simulations, permafrost degrades during the simulation period, following the warming meteorological conditions in the same period. For the simulation with snow-free rock wall (Figures 2A,B), the geometries of the thermal isoclines indicate that cold temperatures stretch from the steep rock wall below the talus apex and enter the talus slope from its backside both in 1881-1885 and in 2001-2005. In 2001-2005, the saturated zone of the talus slope and the solid bedrock below the knickpoint remains partly frozen, although the temperature regime at the surface of the talus slope does not correspond to permafrost conditions at depth. The situation is different for the control run (Figures 2C,D), were the modeled rock wall temperatures are relatively warm with minimum temperatures in the range $0-1^{\circ} \mathrm{C}$ for both the $1881-1885$ and the $2001-2005$ averages. Below the talus apex, both the talus slope and the solid bedrock are frozen in 1881-1885, while the same areas are completely thawed in 2001-2005. These model results suggest that the snow-free rock wall has a cooling effect on the ground thermal regime both in the rock wall itself and in adjacent areas.

Furthermore, we test the sensitivity of the modeled cooling effect from the steep rock wall through a comparison of simulations with different elevations and thus different temperature conditions, Case 1-3 (Table 3). In (Figure 3) we compare average ground temperatures over the 2001-2005 period for Case 1-3 simulations with snow-free rock walls with the respective control runs. For the simulations with snow-free rock walls (Figures $\mathbf{3 A - C}$ ), the saturated part of the talus slope is mainly or partly frozen for all three cases. For the control simulations (Figures 3D-F), the ground is completely thawed below the talus apex for both Case 1 and Case 2 simulations, while a small part of the saturated zone of the talus slope and the solid bedrock is frozen for the colder temperature regime in Case 3. Test simulations performed with unfrozen initial conditions indicate that the cooling effect of steep rock walls is insensitive to the choice of initial conditions.

All model parameters, except rock wall surface temperatures, were identical for the Case 1-3 and the Case 1-3 Control simulation sets. Thus, the distinct difference in modeled temperatures below the talus apex is controlled by the rock wall surface temperature. The cooling effect of the steep rock wall was further investigated through a sensitivity study with varying snow cover conditions in the steep rock wall (Figure 4). Comparing the ground temperature conditions for Case 2 with mean annual snow cover thicknesses (AMHS) ranging from $<0.05$ to $0.25 \mathrm{~m}$ (Figures 4B-E) with the uncovered Case 2 (Figure 4A) and Case 2 Control (Figure 4F) indicate that the cooling effect of the steep rock wall is present for all simulated temperature fields. The strength of the effect is, however, clearly dependent on the rock wall snow cover conditions.

In the water-rich zone of the slope, temperatures below the freezing point indicate presence of ice. As a first investigation of the potential ice formation in the talus slope, we have estimated the fraction of frozen ground in the water rich part of the talus slope for the modeled temperature fields (Figure 3). For comparison, the fraction of frozen ground for each simulation was normalized with respect to the frozen area for the coldest simulation, Case 3. The results (Table 4) indicate that the water/ice-saturated part was frozen for all simulations with snow-free rock walls, ranging from 18 to $100 \%$ normalized with respect to Case 3. For the control runs, the talus slope was completely thawed for both Case 1 and Case 2 simulations, while for the Case 3 simulation the estimated frozen fraction was $10 \%$.

\section{Heat Flux and Temperature Gradients}

The simulated conductive cooling effect of the snow-free rock walls was further investigated by assessing the magnitude and direction of the heat fluxes. We present the average direction of heat fluxes in the period 2001-2005 for Case 2 and Case 2 Control simulations. For the simulations with snow-free rock walls (Figure 5A), the directions of the heat fluxes provide a clear evidence that the steep rock wall acts as a cooling mechanism with heat flowing from both, the talus slope and the snowcovered plateau and out through the steep rock wall. For the control runs (Figure 5B), the situation is different with a heat flux pattern mainly controlled by the geothermal heat flow with heat flowing from depth and up toward the surface. Additional ground warming was induced by the surface temperature regime in the snow-covered rock wall and below the flat plateau.

For the simulations with snow-free rock walls, we calculated the average heat flux over 5-year periods along the backside of the talus slope (Figure 5C) from 3 to $30 \mathrm{~m}$ depth below the talus apex. For the upper $20 \mathrm{~m}$, the average heat fluxes over the 5 -year period 2001-2005 were found to be in the range of $100-1000 \mathrm{~mW} / \mathrm{m}^{2}$, 


\section{Average Temperatures Case 2}
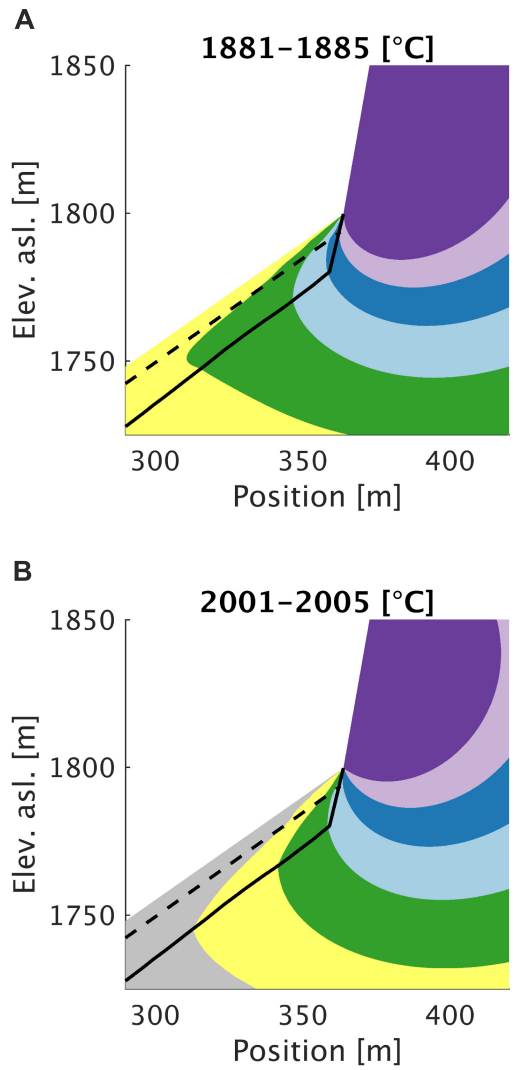

C

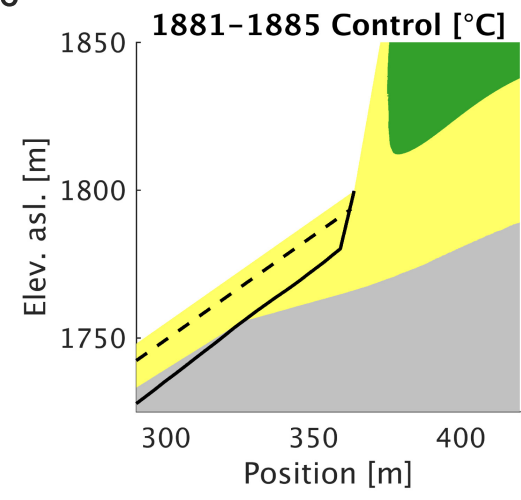

D

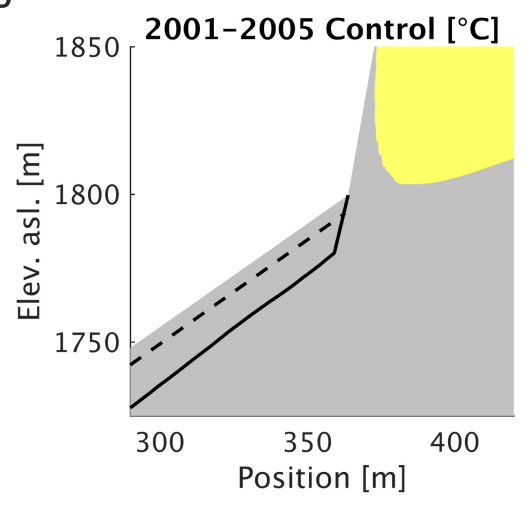

1

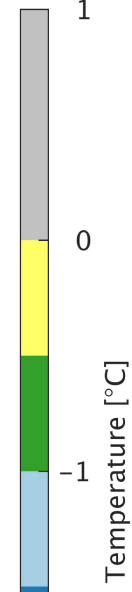

$-3$

FIGURE 2 | Comparison of the modeled temporal evolution of the thermal regime for Case 2 (A,B) and Case 2 Control (C,D) simulations. The comparison is made between average temperatures over two 5-year periods 1881-1885 and 2001-2005. The plotted areas are cut-outs from the numerical domain presented in Figure 1B. Colors indicate temperatures below $0^{\circ} \mathrm{C}$. Simulations are run with elevation $1700-1900 \mathrm{~m}$ asl., with thermal conductivity $\mathrm{K}=3.5 \mathrm{~W} / \mathrm{m}{ }^{\circ} \mathrm{C}$ and geothermal heat flux $50 \mathrm{~mW} / \mathrm{m}^{2}$. Snow covers are implemented along the talus slope for both simulations by means of $n F=0.2$. For the control simulation (C,D), $n F=0.2$ is implemented along the steep rock wall.

with a decreasing magnitude with increasing distance from the talus apex.

Furthermore, we assessed the 5-year average thermal gradients for the Case 2 simulation (Figure 6A). The gradient field indicates that average thermal gradients with magnitude $0.1-0.8^{\circ} \mathrm{C} / \mathrm{m}$ stretch out in a radial distance from the talus apex up to the rock wall surface and down toward the talus slope. The geometry of the thermal gradient field changes abruptly across the boundary between the solid bedrock and the water-rich talus slope. We do not find similar thermal gradient patterns for the control runs (Figure 6B). These results suggest that the rock wall surface conditions have a significant impact on the thermal gradients both in the talus slope and in the steep rock wall. Reducing the conductivity in the talus by a factor of 5 (Figure 6C), results in increasing thermal gradients in the talus and a sharper discontinuous jump between the solid rock and the talus, as compared to the original Case 2 simulation (Figure 6A). An additional Case 2 simulation with increased resolution along the rock-talus-boundary (Figure 6D) is nearly identical with the original Case 2 simulations (Figure 6A), which demonstrates that the simulation results are not influenced by our choice of mesh.

\section{DISCUSSION}

\section{Limitations of the Model Study}

(1) The real heat flow system between steep rock walls and talus accumulations in mountain areas includes the combined effect of heat conduction and air flow driven convective processes through blocky surface layers (Haeberli et al., 2006; Scherler et al., 2014) or fracture systems in rock walls (e.g., Gischig et al., 2011; Blikra and Christiansen, 2014). In our study, we have included only conductive heat flow to investigate heat flow between steep rock walls and talus slopes and its potential influence on the thermal regime of talus slopes. Nevertheless, our study demonstrates that conductive heat flow may induce significant thermal gradients in solid bedrock and provide heat loss through steep rock walls that may influence the thermal conditions in adjacent talus slopes, acting as an additional contribution to convective cooling processes.

(2) The surface temperature conditions assumed for our simulations are simplified and do not incorporate all natural variations, such as aspect-dependent radiation 


\section{Average Temp 2001-2005}
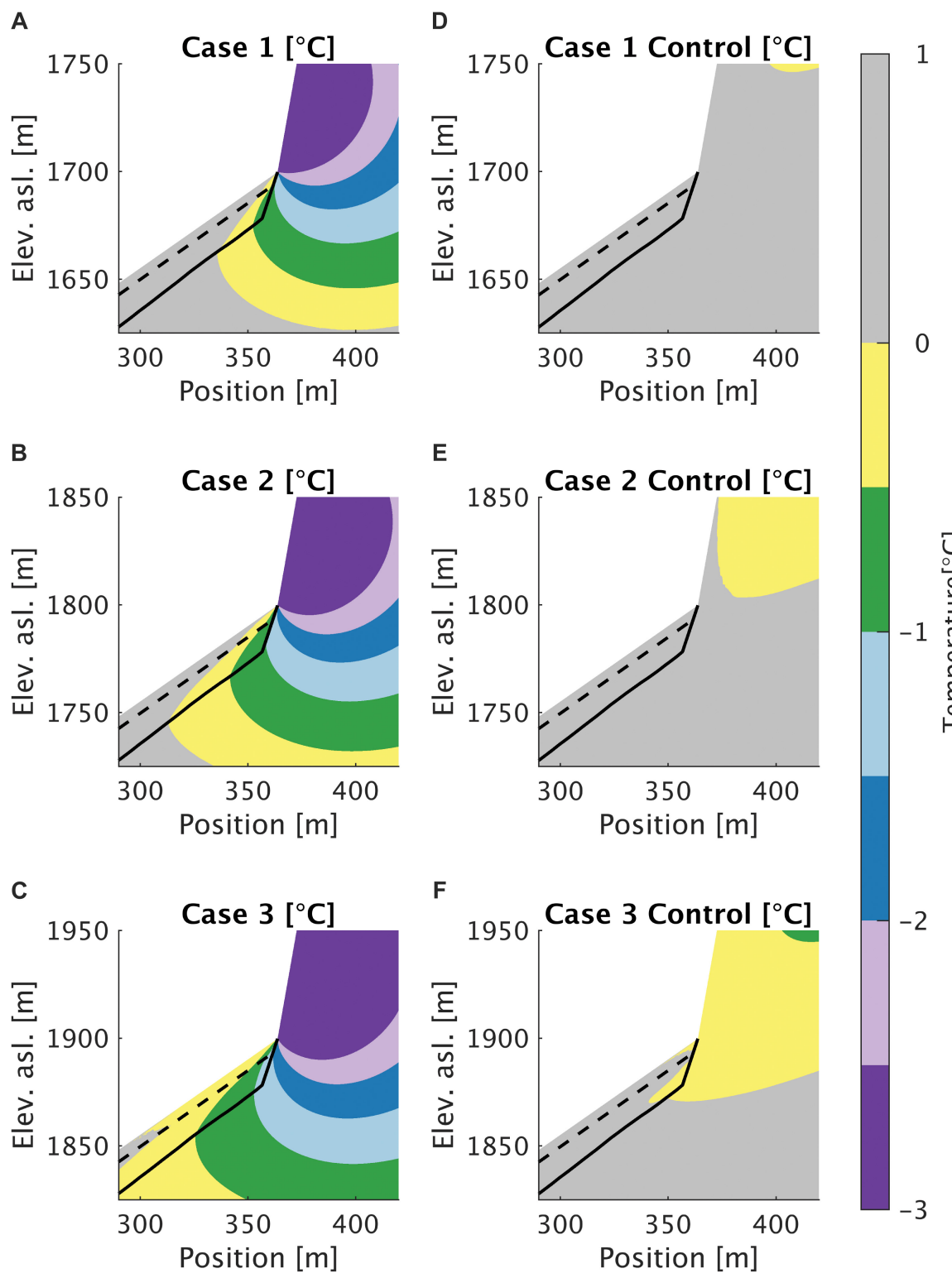

FIGURE 3 | Comparison of simulated average ground temperatures in the period 2001-2005 for the geometry situated at different elevations, Case 1-3 (A-C) and Case 1-3 Control (D-F). The plotted areas are cut-outs from the numerical domain presented in Figure 1B. Colors indicate temperatures below $0^{\circ} \mathrm{C}$. All simulations are run with mineral thermal heat conductivity $\mathrm{k}=3.5 \mathrm{~W} / \mathrm{m}^{\circ} \mathrm{C}$ and geothermal heat flux $50 \mathrm{~mW} / \mathrm{m}^{2}$. Snow covers are implemented along the talus slope for both simulations by means of $n F=0.2$. For the control simulations, $n F=0.2$ is implemented along the steep rock wall.

(Gruber et al., 2003) and effects due to partly snowcovered rock wall conditions (Gardner, 1969; Hasler et al., 2011; Haberkorn et al., 2015). For air temperatures below $0^{\circ} \mathrm{C}$, we reduced the ground surface forcing along the talus slope and the flat plateau by means of empirical $\mathrm{N}$-factors representing a static snow cover during winter. The assumption regarding snow-free rock wall conditions is probably the most important uncertainty incorporated in our numerical study. A sensitivity study of the effect of different snow cover thicknesses in the steep rock wall
(Figure 4) indicates that the cooling effect of the steep rock wall is present, but decreasing for increasing snow cover thickness. Further, the influence of snow melt and changing ground water content due to water transport and the effect of solar radiation on rock wall surface temperatures are not included in our simulations. To test the effect of the latter simplification, we performed additional simulations with increased $\left(1^{\circ} \mathrm{C}\right)$ rock wall temperatures, which is the aspect offset indicated by a monitoring study of rock wall surface temperatures in Norway (Hipp et al., 2014). These 


\section{Case 2 : Snow Cover Sensitivity}

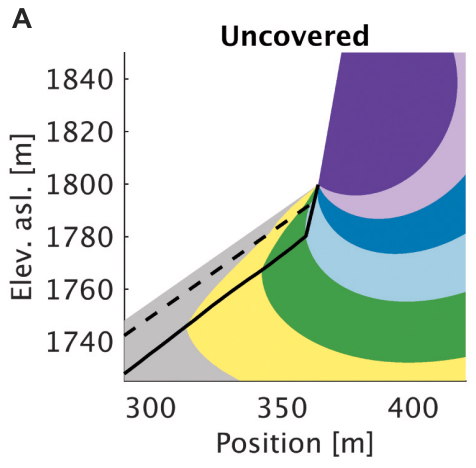

B
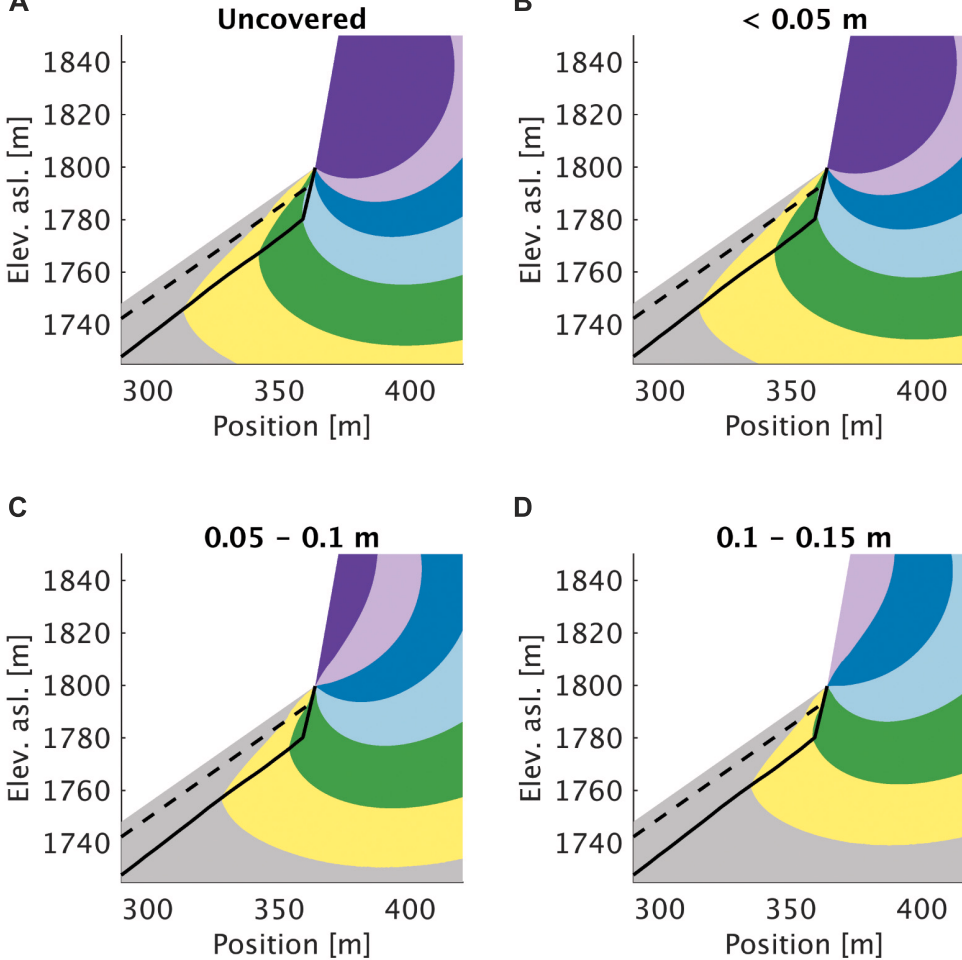

D
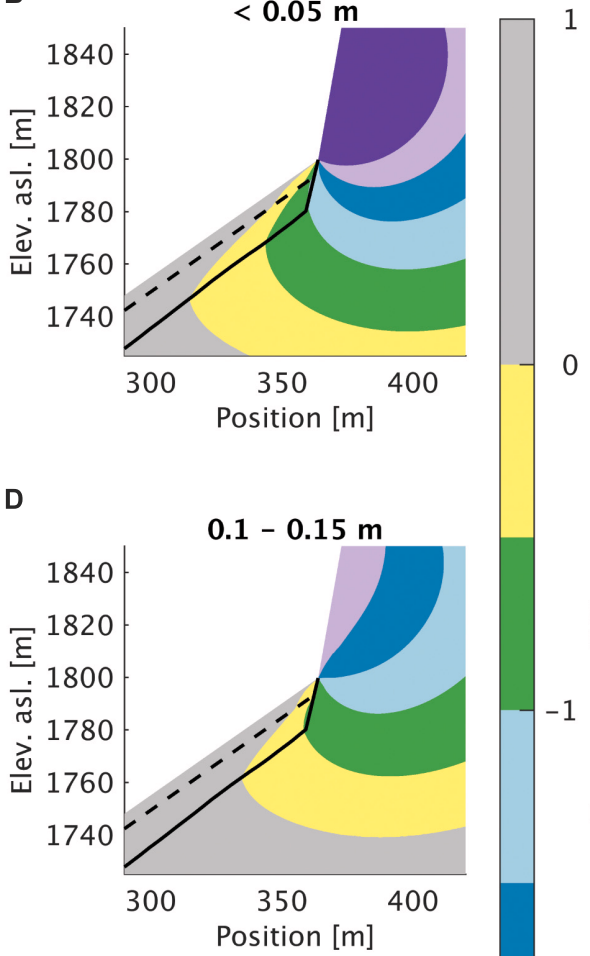

1

0

$\mathbf{E}$

$\mathbf{F}$
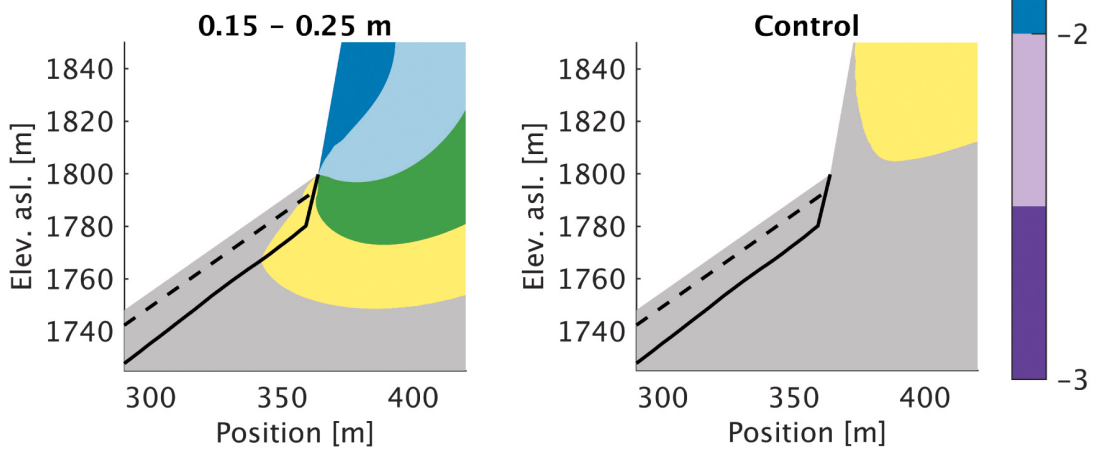

FIGURE 4 | Sensitivity study of heat flow between snow-covered talus slopes $(n F=0.2)$ and steep rock walls with different annual mean snow thicknesses (AMHS) following Gisnås et al. (2013). (A) $n F=1$ (Snow-free) (B) $n F=0.95$ (AMHS: $<0.05 \mathrm{~m}$ ) (C) $n F=0.7$ (AMHS: 0.05-0.1 m) (D) $n F=0.6$ (AMHS: $0.1-0.15 \mathrm{~m})$ (E) $n F=0.5$ (AMHS: $0.15-0.25 \mathrm{~m})$ (F) $n F=0.2$ (AMHS: $>0.8 \mathrm{~m}$ ).

simulations show that increasing rock wall temperatures decrease the cooling effect of the steep rock wall, but the overall process pattern described in this study is not changed.

\section{Do Steep Rock Walls Influence the Temperature in Adjacent Talus Slopes?}

In general, the low conductivity of air reduces the effect of conductive heat flow on the thermal regime for porous talus slopes. Therefore, air circulation through the porous surface layer and though circulation patterns in the talus slopes are considered to be the governing heat flow processes for talus slopes (e.g., Morard et al., 2008; Wicky and Hauck, 2017). For snow-covered talus slopes, the thermal insulation of snow may induce both

TABLE 4 | Fraction of $T \leq 0^{\circ} \mathrm{C}$ in water rich part of talus slope for the 2001-2005 average temperature field for Case 1-3 simulations.

\begin{tabular}{lccc}
\hline $\begin{array}{l}\text { Simulation Elevation } \\
\text { (m asl.) }\end{array}$ & $\begin{array}{c}\text { Case 1 } \\
\mathbf{1 6 0 0 - 1 8 0 0}\end{array}$ & $\begin{array}{c}\text { Case 2 } \\
\mathbf{1 7 0 0 - 1 9 0 0}\end{array}$ & $\begin{array}{c}\text { Case 3 } \\
\mathbf{1 9 0 0 - 2 0 0 0}\end{array}$ \\
\hline Main run (\%) & 18 & 42 & 100 \\
Control run (\%) & 0 & 0 & 10
\end{tabular}


A

Heat Flux Direction 2001-2005

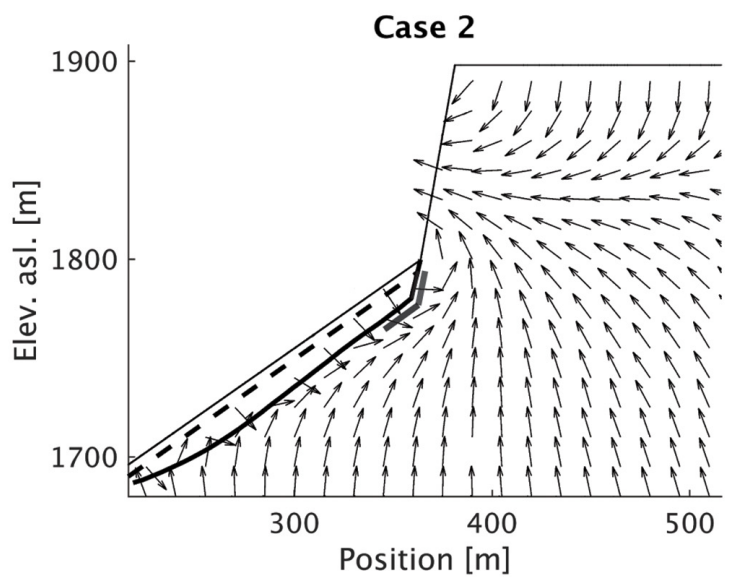

B

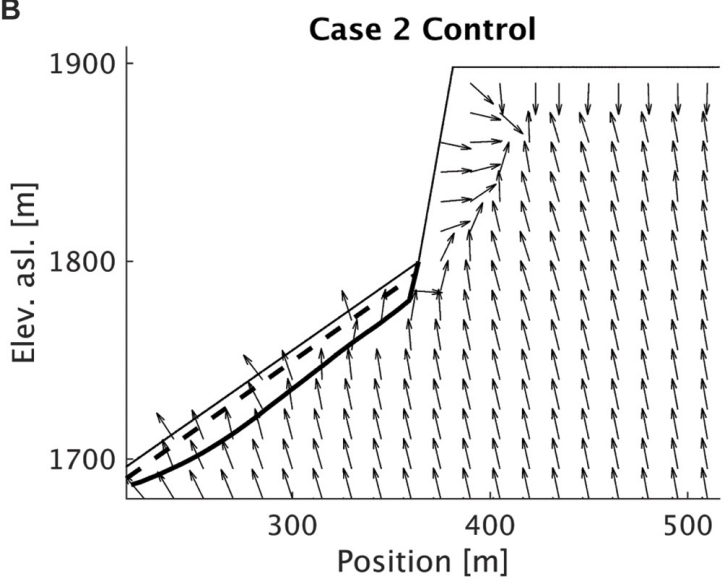

C

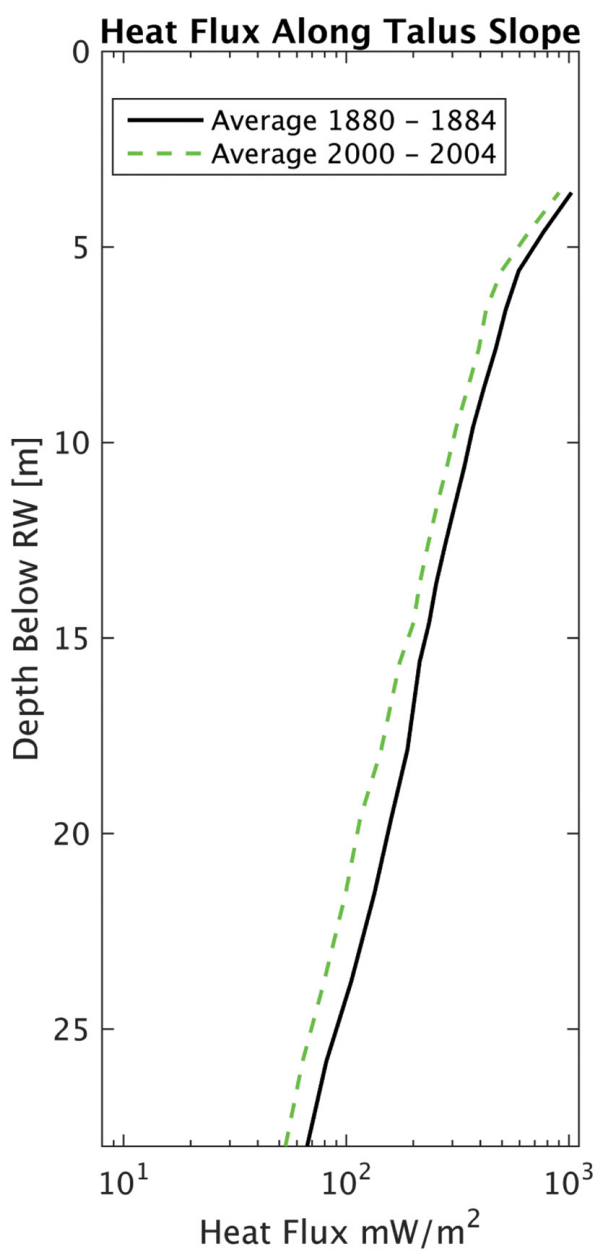

FIGURE 5 | (A,B) Heat flux directions over the 5-year period 2001-2005 for Case 2 (A) and Case 2 Control (B) simulations. The simulations are run with elevation 1700-1900 m asl., with mineral thermal conductivity $k=3.5 \mathrm{~W} / \mathrm{m}^{\circ} \mathrm{C}$ and geothermal heat flux $50 \mathrm{~mW} / \mathrm{m}^{2}$. Snow covers are implemented along the talus slope for both simulations by means of $n F=0.2$. For the control simulation (B), $n F=0.2$ is also implemented along the steep rock wall. (C) Average heat fluxes along the backside of the talus slope from 3 to $30 \mathrm{~m}$ depth below the talus apex [marked with gray line in panel (A)] in 1881-1885 and 2001-2005 for the Case 2 simulation with snow-free rock wall.

a reduction of airflow through the blocky surface layer and induction of conductive effects such as near-surface cooling effect as modeled by Gruber and Hoelzle (2008) in addition to our proposed cooling effect from steep rock walls.

Our simulations of heat flow between steep rock walls and adjacent talus slopes indicate that conductive heat flow in steep and snow-free rock walls may cool down the talus slope from behind (Figures 2, 3) and in turn facilitate the existence of ice (Table 4). Thus, the conductive heat flow from the backside of the talus slope is of similar or larger order of magnitude than the conductive heat flow through the snow-covered talus. For our numerical set-up, the applied rock wall temperatures (see section "Limitations of the Model Study"), the choice of thermal conductivity and the choice of geometry control the strength of the cooling effect. The geometry represents a realistic rock-wall-talus situation and the chosen parameters are in correspondence with field measurements (Morard et al., 2008; Scapozza et al., 2011). Other talus geometries than our model geometry may change the nature of our proposed cooling effect. Test simulations confirm that increasing thermal conductivity increases the depth to which the cooling effect of the steep rock wall reaches. Our choice of thermal conductivity $\left(k_{m}=3.5 \mathrm{~W} / \mathrm{m}^{\circ} \mathrm{C}\right)$ is in the range of thermal conductivities calculated from the average mineral composition at Juvvasshøe (Isaksen et al., 2001). This value is typical for granite-rich igneous rock, such as the Norwegian basement rock (Clauser and Huenges, 2013), but does not represent a situation with strong conductive cooling as values up to $k_{m}=7 \mathrm{~W} / \mathrm{m}^{\circ} \mathrm{C}$ can be found in quartz rich areas.

The modeled cooling effect is largest close to the talus apex and fades out with increasing distance from this point. For the upper $20 \mathrm{~m}$, the average heat fluxes over the 5-year 


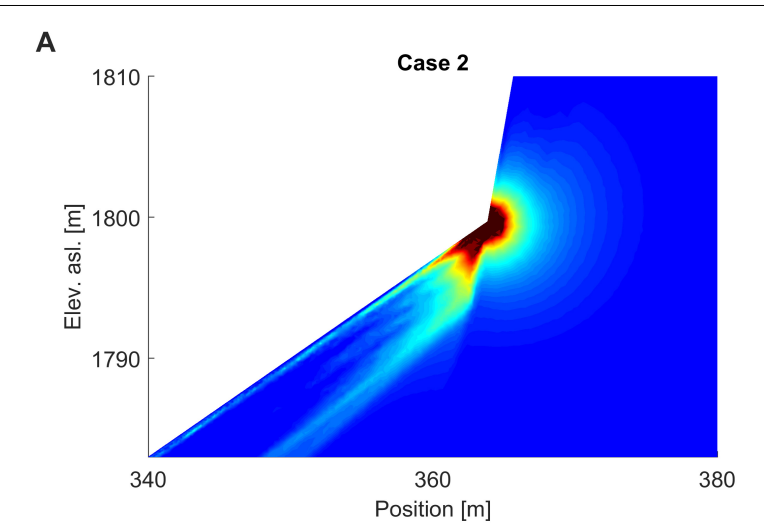

C

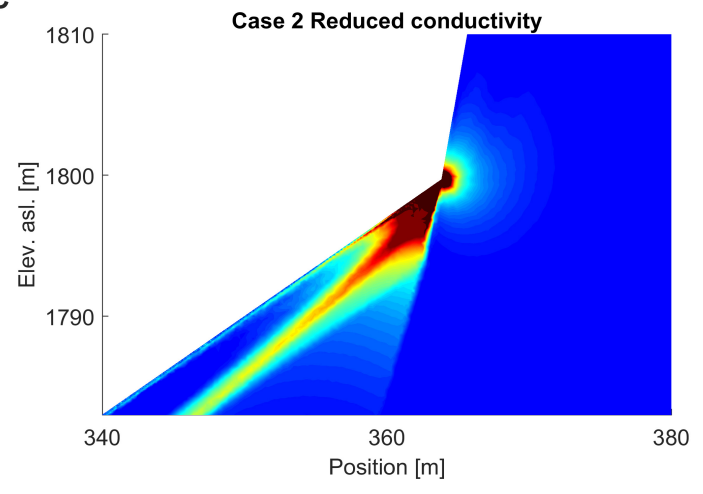

B

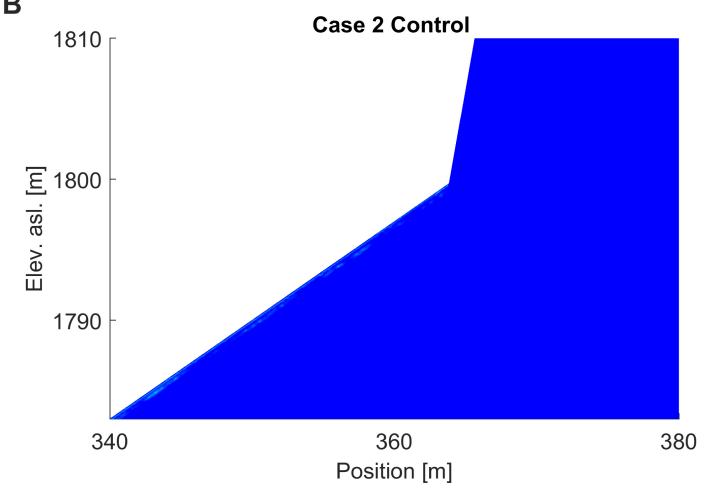

D

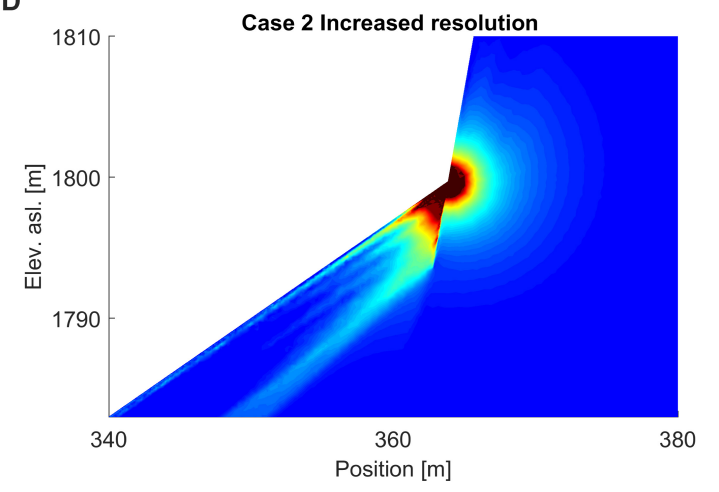

FIGURE 6 | Comparison of the magnitudes of thermal gradients over the 5-year period 2001-2005 for (A) Case 2 and (B) Case 2 Control simulations. In (C) and (D) we present the same 5-year average thermal gradients for Case 2 simulations with thermal conductivity in the talus reduced by a factor of five and increased resolution along the rock-talus boundary, respectively. Colors indicate magnitude of the temperatures gradients.

period 2001-2005 were found to be in the range of 100$1000 \mathrm{~mW} / \mathrm{m}^{2}$, which is a significant factor in the energy balance of the talus slope compared to the magnitude of the geothermal heat flux, $50 \mathrm{~mW} / \mathrm{m}^{2}$. In a modeling study of a rock glacier in the Swiss Alps, Scherler et al. (2014), added a seasonally dependent source/sink term to account for air flow driven heat flow and a deviation term to close a measured energy balance. Their choice of the winter sink term due to air flow in the model $\left(28.9 \mathrm{~W} / \mathrm{m}^{2}\right)$ is significantly larger than our modeled conductive contribution, while their estimated winter deviation term for the measured energy balance $\left(5.5\right.$ to $\left.-0.9 \mathrm{~W} / \mathrm{m}^{2}\right)$ is in the same range. The magnitude of these terms were, however, estimated from an observed deviation between measured and modeled borehole temperatures or measured deviations in the energy balance, respectively. As our modeled conductive cooling effect may contribute to such deviations between measured temperatures and model experiments, where the potential effect of conductive cooling from steep rock walls is excluded, we can not identify whether our modeled effect is included in the heat sink or deviation terms described in the study from the Swiss Alps. In a recent modeling study, Wicky and Hauck (2017) found that conductive cooling alone could not induce significant temperature differences between the upper and lower parts of a talus slope. Our modeled conductive contribution does not contradict this study as we propose that the cooling effect arises from the nearby steep rock wall, a feature that is not included in the study by Wicky and Hauck (2017).

Though we present the results as 5-year averages, the cooling effect from steep rock walls is a winter phenomenon. Thus, the modeled cooling effect from the steep rock wall is active during winter when the chimney effect may induce transport of warm air from the lower to the upper parts of talus slopes (e.g., Delaloye and Lambiel, 2005; Morard et al., 2008). The chimney-effect leads to a strong damping of the conductive effect within unfrozen (ice-free) talus material and it is clear that the warming chimney-effect would dominate over our proposed cooling effect within the talus material. However, at this meeting point, stronger thermal gradients may arise due to the temperature difference between the warm air flow through the talus and the potential cooling from the backside of the talus. Thus, the combined effect of these heat flow mechanisms may reduce the importance of the potential cooling effect on the talus temperature regime, but can lead to even stronger thermal gradients than we have modeled in our purely conductive study as well. These strong thermal gradients may in turn have implications for frost weathering processes.

\section{Geomorphological Implications}

Our modeling study of heat flow in the transition area between steep slopes and flatter topography may have some important 
implications for periglacial slope stability problems involving both frost weathering and frost creep processes.

\section{Destabilization of Steep Rock Walls: Frost Weathering}

Decreasing stability of steep rock walls in permafrost terrain is a primary challenge and an important issue for mountain permafrost research (Haeberli et al., 2010). While freeze-thaw mechanisms may attribute significant rock strength reduction for frequent temperature fluctuations across the freezing point (Jia et al., 2015), segregation ice growth is most efficient in the frost-cracking window $\left(-8\right.$ to $\left.-3^{\circ} \mathrm{C}\right)$. Further, it is sensitive to the amount of available water, the time exposed to temperatures in the frost-cracking window and the magnitude of the thermal gradients (Hallet et al., 1991; Anderson, 1998; Hales and Roering, 2007). With our numerical study, we demonstrate that thermal gradients $\left(0.1-0.8^{\circ} \mathrm{C} / \mathrm{m}\right)$ build up around the transition between snow-free steep rock walls and talus slopes (Figure 6A) for rock wall temperatures in or close to the frost-cracking window (Figure 5C). Our modeled thermal gradients are in the lower end of the thermal gradient magnitude range for which Hales and Roering (2007) predict ice segregation (0.4$20^{\circ} \mathrm{C} / \mathrm{m}$ ), but our simulations of heat flow in steep rock walls indicate that heat conduction may contribute to mechanical breakdown of the solid rock wall and to the production of talus material. The simulation with reduced conductivity in the talus (Figure 6C) indicates that the reduction increases the influence of the rock wall on the low conductivity talus material. While the cooling effect of the steep rock wall increases, the thermal gradients and the potential for rock mass weakening in the steep rock wall decrease. Thus, this sensitivity study indicates that our qualitative conclusions are solid though the magnitude of the effects are dependent on the ratio of thermal conductivities between the solid rock and the talus material.

Direct measurements of temperature conditions close to transition areas between rock walls and talus slopes are scarce, but field observations indicate that snow cover variations influence frost weathering processes in permafrost environment. Through a summer study of snow patches and their thermal relation with rock wall temperatures, Gardner (1969) found frequent freezethaw cycles at the edge of remaining snow patches that may have induced intensive frost weathering and potentially developed undercuts at the base of steep rock walls. Similar results were obtained by Berrisford (1991) who found that presence of snow patches in the vicinity of rock walls affect frost weathering processes and Ødegård et al. (1995) who attributed enhanced frost weathering to thermal gradients induced by snow cover variations in steep rock cliffs at Svalbard. Similar favorable conditions for rock weathering and rock wall undercutting have been identified in a study of frost weathering in cirque glacier settings (Sanders et al., 2012).

\section{Creep of Ice-Rich Talus Slopes: Existence of Ice}

A second slope stability problem in permafrost terrain involves creep of perennially frozen talus slopes with high ice content, i.e., talus slopes that evolve into rock glaciers.
TABLE 5 | Average heat loss from the backside of the talus slope together with the corresponding potential formation of ice for simulations with snow-free steep rock walls.

\begin{tabular}{lccc}
\hline $\begin{array}{l}\text { Simulation Elevation } \\
\text { (m asl.) }\end{array}$ & $\begin{array}{c}\text { Case 1 } \\
\mathbf{1 6 0 0 - 1 8 0 0}\end{array}$ & $\begin{array}{c}\text { Case 2 } \\
\mathbf{1 7 0 0 - 1 9 0 0}\end{array}$ & $\begin{array}{c}\text { Case 3 } \\
\mathbf{1 9 0 0 - 2 0 0 0}\end{array}$ \\
\hline $\begin{array}{l}\text { Spatial average heat } \\
\text { flux }\left(\mathrm{W} / \mathrm{m}^{2}\right)\end{array}$ & 0.26 & 0.28 & 0.29 \\
$\begin{array}{l}\text { Potential formation of } \\
\text { ice }(\mathrm{cm} / \text { year) }\end{array}$ & 2.5 & 2.6 & 2.7 \\
\hline
\end{tabular}

Our simulations indicate that sub-zero temperatures are maintained in water-rich talus material (Table 4) due to conductive heat flow between snow-free rock walls and talus slopes (Figure 3).

Further, we estimate roughly the potential ice formation in the talus slope through a comparison of the simulated heat flux budget across the bedrock-talus boundary with the heat loss required to form ice. If we compute the 5-year average heat flux along the upper 3-30 $\mathrm{m}$ of the backside of the talus material as presented for Case 2 (Figure 5C), we obtain a heat loss which corresponds to the production of $\sim 2-3 \mathrm{~cm} /$ year of ground ice from refreezing of water (Table 5). We emphasize that our calculation neither includes the thermal dynamics of infiltrating and refreezing water at the top of the talus slope, nor the effect of convective heat transport.

Both ice-rich talus slopes and talus accumulations with thin layers of ice are sensitive to creep, in particular when the ice temperature is close to the melting temperature (Haeberli et al., 2010). Though the conductive contribution to the existence of ice may be limited, our numerical simulations indicate that heat loss through snow-free rock walls may contribute to both formation and subsequent removal of talus material through frost weathering processes and existence of internal ice layers, both of which are essential for development of talus derived rock glaciers.

\section{CONCLUSION}

With our simplified numerical study of the thermal regime in steep snow-free rock walls, we have demonstrated that thermal gradients associated with frost weathering and evolution of landscapes may be recognized in a simplified 2D numerical study of conductive heat flow in steep rock walls. Our numerical simulations indicate that thermal gradients are maintained in transition areas between snow-free rock walls and snow-covered talus slopes. Thus, conductive heat flow may be an important heat flow process that influences the temperature conditions between steep rock walls and talus slopes, but these numerical results need to be validated against field observations to investigate whether they reflect the natural situation.

- Conductive heat flow in steep rock walls with little or no winter snow cover may influence the temperature regime in adjacent talus slopes due to a cooling effect of the steep rock walls. 
- Strong thermal gradients that arise at the boundary between snow-covered talus slopes and snow-free rock walls may contribute to frost weathering processes and rock mass weakening of the steep bedrock.

\section{AUTHOR CONTRIBUTIONS}

KM wrote the numerical code and major part of the manuscript, and performed the numerical simulations. SW conceived the study and provided support for the numerical simulations in addition to his contributions to the manuscript. BE contributed significantly to the study and the manuscript.

\section{REFERENCES}

Anderson, R. S. (1998). Near-surface thermal profiles in alpine bedrock: implications for the frost weathering of rock. Arctic Alpine Res. 30, 362-372. doi: $10.2307 / 1552008$

Berrisford, M. S. (1991). Evidence for enhanced mechanical weathering associated with seasonally late-lying and perennial snow patches, Jotunheimen, Norway. Permafrost Periglacial Process. 2, 331-340. doi: 10.1002/ppp.3430020408

Blikra, L. H., and Christiansen, H. H. (2014). A field-based model of permafrostcontrolled rockslide deformation in northern Norway. Geomorphology 208, 34-49. doi: 10.1016/j.geomorph.2013.11.014

Carson, M. A. (1977). Angles of repose, angles of shearing resistance and angles of talus slopes. Earth Surface Process. 2, 363-380. doi: 10.1002/esp.3290020408

Clauser, C., and Huenges, E. (2013). "Thermal conductivity of rocks and minerals," in Rock Physics \& Phase Relations: A Handbook of Physical Constants, ed. T. J. Ahrens (Washington, DC: American Geophysical Union), 105-126.

Dabrowski, M., Krotkiewski, M., and Schmid, D. W. (2008). MILAMIN: MATLABbased finite element method solver for large problems. Geochem. Geophys. Geosyst. 9:Q04030. doi: 10.1029/2007GC001719

Delaloye, R., and Lambiel, C. (2005). Evidence of winter ascending air circulation throughout talus slopes and rock glaciers situated in the lower belt of alpine discontinuous permafrost (Swiss Alps). Norsk Geografisk TidsskriftNorwegian J. Geography 59, 194-203. doi: 10.1080/00291950510020673

Etzelmüller, B., Romstad, B., and Fjellanger, J. (2007). Automatic regional classification of topography in Norway. Norwegian J. Geol. 87, 167-180.

Farbrot, H., Etzelmüller, B., Guð̊mundsson, Á, Humlum, O., Kellerer-Pirklbauer, A., Eiken, T., et al. (2007). Rock glaciers and permafrost in Trollaskagi, northern Iceland. Zeitschrift Fur Geomorphologie 51, 1-16. doi: 10.1127/0372-8854/007/ 0051S2-0001

Farbrot, H., Hipp, T. F., Etzelmüller, B., Isaksen, K., Ødegård, R. S., Schuler, T. V., et al. (2011). Air and ground temperature variations observed along elevation and continentality gradients in Southern Norway. Permafrost Periglacial Process. 22, 343-360. doi: 10.1002/ppp.733

Gardner, J. (1969). Snowpatches: their influence on mountain wall temperatures and the geomorphic implications. Geografiska Ann. Ser APhys. Geography 51, 114-120. doi: 10.2307/520624

Gischig, V. S., Moore, J. R., Evans, K. F., Amann, F., and Loew, S. (2011). Thermomechanical forcing of deep rock slope deformation: 2. The Randa rock slope instability. J. Geophys. Res. Earth Surf. 116:F04011. doi: 10.1029/ 2011JF002007

Gisnås, K., Etzelmüller, B., Farbrot, H., Schuler, T. V., and Westermann, S. (2013). CryoGRID 1.0: permafrost distribution in norway estimated by a spatial numerical model. Permafrost Periglacial Process. 24, 2-19. doi: 10.1002/ppp. 1765

Gruber, S., and Haeberli, W. (2007). Permafrost in steep bedrock slopes and its temperature-related destabilization following climate change. J. Geophys. Res. 112:F02S18. doi: 10.1029/2006JF000547

Gruber, S., and Hoelzle, M. (2008). "The cooling effect of coarse blocks revisited: a modeling study of a purely conductive mechanism," in Proceedings of the 9th

\section{FUNDING}

The study was initiated and carried out in the Department of Geosciences, University of Oslo, who funded most of the work. Additional funding was provided by the Western Norway University of Applied Sciences, and the study is an integrated part of the RCN (Research Council of Norway)-funded CryoWALL project (243784/CLE).

\section{ACKNOWLEDGMENTS}

We sincerely thank the reviewers for valuable suggestions and comments, which improved the manuscript.

International Conference on Permafrost, (Fairbanks, AK: Institute of Northern Engineering University of Alaska), 557-561.

Gruber, S., Hoelzle, M., and Haeberli, W. (2004). Rock-wall temperatures in the Alps: modelling their topographic distribution and regional differences. Permafrost Periglacial Process. 15, 299-307. doi: 10.1002/ppp.501

Gruber, S., Peter, M., Hoelzle, M., Woodhatch, I., and Haeberli, W. (2003). "Surface temperatures in steep alpine rock faces-a strategy for regional-scale measurement and modelling," in Proceedings of the 8th International Conference on Permafrost, (Zurich: AA Balkema), 325-330.

Haberkorn, A., Hoelzle, M., Phillips, M., and Kenner, R. (2015). Snow as a driving factor of rock surface temperatures in steep rough rock walls. Cold Regions Sci. Technol. 118, 64-75. doi: 10.1016/j.coldregions.2015.06.013

Haeberli, W., Hallet, B., Arenson, L., Elconin, R., Humlum, O., Kääb, A., et al. (2006). Permafrost creep and rock glacier dynamics. Permafrost Periglacial Process. 17, 189-214. doi: 10.1002/ppp.561

Haeberli, W., Noetzli, J., Arenson, L., Delaloye, R., Gärtner-Roer, I., Gruber, S., et al. (2010). Mountain permafrost: development and challenges of a young research field. J. Glaciol. 56, 1043-1058. doi: 10.3189/002214311796406121

Hales, T. C., and Roering, J. J. (2007). Climatic controls on frost cracking and implications for the evolution of bedrock landscapes. J. Geophys. Res. 112:F02033. doi: 10.1029/2006JF000616

Hallet, B., Walder, J. S., and Stubbs, C. W. (1991). Weathering by segregation ice growth in microcracks at sustained subzero temperatures: verification from an experimental study using acoustic emissions. Permafrost Periglacial Process. 2, 283-300. doi: 10.1002/ppp.3430020404

Hanssen-Bauer, I., and Nordli, P. Ø. (1998). Annual and Seasonal Temperature Variations in Norway 1876-1997. DNMI report 25. Oslo: Norwegian Meteorological Institute, 98.

Hasler, A., Geertsema, M., Foord, V., Gruber, S., and Noetzli, J. (2015). The influence of surface characteristics, topography and continentality on mountain permafrost in British Columbia. Cryosphere 9, 1025-1038. doi: 10.5194/tc-91025-2015

Hasler, A., Gruber, S., and Beutel, J. (2012). Kinematics of steep bedrock permafrost. J. Geophys. Res. 117:F01016. doi: 10.1029/2011JF001981

Hasler, A., Gruber, S., and Haeberli, W. (2011). Temperature variability and offset in steep alpine rock and ice faces. Cryosphere 5, 977-988. doi: 10.5194/tc-5-9772011

Hillel, D. (1982). Fundamentals of Soil Physics. Cambridge, MA: Academic Press.

Hipp, T., Etzelmüller, B., and Westermann, S. (2014). Permafrost in alpine rock faces from jotunheimen and hurrungane, Southern Norway. Permafrost Periglacial Process. 25, 1-13. doi: 10.1002/ppp.1799

Isaksen, K., Heggem, E. S. F., Bakkehøi, S., Ødegård, R. S., Eiken, T., Etzelmüller, B., et al. (2003). "Mountain permafrost and energy balance on Juvvasshøe, southern Norway," in Proceedings 8th International Conference on Permafrost, Zurich, Switzerland, eds M. Phillips, S. M. Springmann, and L. U. Arenson (Lisse: Swets Zeitlinger), 467-472.

Isaksen, K., Holmlund, P., Sollid, J. L., and Harris, C. (2001). Three deep alpinepermafrost boreholes in Svalbard and Scandinavia. Permafrost Periglacial Process. 12, 13-25. doi: 10.1002/Ppp.380 
Japsen, P., Bonow, J. M., Green, P. F., Chalmers, J. A., and Lidmar-Bergström, K. (2006). Elevated, passive continental margins: long-term highs or Neogene uplifts? New evidence from West Greenland. Earth Planet. Sci. Lett. 248, 330-339. doi: 10.1016/j.epsl.2006.05.036

Jia, H., Xiang, W., and Krautblatter, M. (2015). Quantifying rock fatigue and decreasing compressive and tensile strength after repeated freezethaw cycles. Permafrost Periglacial Process. 26, 368-377. doi: 10.1002/ppp. 1857

Krautblatter, M., Funk, D., and Günzel, F. K. (2013). Why permafrost rocks become unstable: a rock-ice-mechanical model in time and space. Earth Surf. Process. Landforms 38, 876-887. doi: 10.1002/esp.3374

Krautblatter, M., Huggel, C., Deline, P., and Hasler, A. (2012). Research perspectives on unstable high-alpine bedrock permafrost: measurement, modelling and process understanding. Permafrost Periglacial Process. 23, 80-88. doi: 10.1002/ppp.740

Lilleøren, K. S., and Etzelmüller, B. (2011). A regional inventory of rock glaciers and ice-cored moraines in Norway. Geografiska Ann. Ser. A Phys. Geography 93, 175-191. doi: 10.1111/j.1468-0459.2011.00430.x

Magnin, F., Deline, P., Ravanel, L., Noetzli, J., and Pogliotti, P. (2015). Thermal characteristics of permafrost in the steep alpine rock walls of the Aiguille du Midi (Mont Blanc Massif, 3842 m a.s.l). Cryosphere 9, 109-121. doi: 10.5194/tc9-109-2015

Magnin, F., Westermann, S., Pogliotti, P., Ravanel, L., Deline, P., and Malet, E. (2016). Snow control on active layer thickness in steep alpine rock walls (Aiguille du Midi, 3842ma. sl, Mont Blanc massif). Catena 149, 648-662. doi: 10.1016/j.catena.2016.06.006

Matsuoka, N. (2008). Frost weathering and rockwall erosion in the southeastern Swiss Alps: long-term (1994-2006) observations. Geomorphology 99, 353-368. doi: 10.1016/j.geomorph.2007.11.013

Mohr, M. (2008). New Routines for Gridding of Temperature and Precipitation Observations for "seNorge. no". Met. no Report 8. Oslo: Norwegian meteorological Institute,

Morard, S., Delaloye, R., and Dorthe, J. (2008). "Seasonal thermal regime of a mid-latitude ventilated debris accumulation," in Proceedings of the 9th International Conference on Permafrost, eds D. L. Kane and K. M. E. Hinkel (Fairbanks, AK: Institute of Northern Engineering University of Alaska), 1233-1238.

Murton, J. B., Peterson, R., and Ozouf, J.-C. (2006). Bedrock fracture by ice segregation in cold regions. Science 314, 1127-1129. doi: 10.1126/science. 1132127

Myhra, K. S., Westermann, S., and Etzelmüller, B. (2017). Modelled distribution and temporal evolution of permafrost in steep rock walls along a latitudinal transect in Norway by CryoGrid 2D. Permafrost Periglacial Process 28, 172-182. doi: $10.1002 /$ ppp. 1884

Noetzli, J., and Gruber, S. (2009). Transient thermal effects in Alpine permafrost. Cryosphere 3, 85-99. doi: 10.5194/tc-3-85-2009

Ødegård, R., Etzelmüller, B., Vatne, G., and Sollid, J. L. (1995). "Near-surface spring temperatures in an Arctic coastal rock cliff: possible implications for rock breakdown," in Steepland Geomorphology, ed. O. Slaymaker (Hoboken, NJ: John Wiley \& Sons), 89-102.

Pascal, C., Elvebakk, H., and Olesen, O. (2010). "An assessment of deep geothermal resources in Norway," in Proceedings of the World Geothermal Congress, Bali, 25-29.
Riseborough, D., Shiklomanov, N., Etzelmuller, B., Gruber, S., and Marchenko, S. (2008). Recent advances in permafrost modelling. Permafrost Periglacial Process 19, 137-156. doi: 10.1002/ppp.615

Roy, R., Beck, A., and Touloukian, Y. (1981). Thermophysical properties of rocks. Phys. Properties Rocks Miner. 2, 409-502.

Saloranta, T. M. (2012). Simulating snow maps for Norway: description and statistical evaluation of the seNorge snow model. Cryosphere 6, 1323-1337. doi: 10.5194/tc-6-1323-2012

Sanders, J. W., Cuffey, K. M., Moore, J. R., MacGregor, K. R., and Kavanaugh, J. L. (2012). Periglacial weathering and headwall erosion in cirque glacier bergschrunds. Geology 40, 779-782. doi: 10.1130/G33330.1

Sass, O. (2006). Determination of the internal structure of alpine talus deposits using different geophysical methods (Lechtaler Alps, Austria). Geomorphology 80, 45-58. doi: 10.1016/j.geomorph.2005.09.006

Scapozza, C., Lambiel, C., Baron, L., Marescot, L., and Reynard, E. (2011). Internal structure and permafrost distribution in two alpine periglacial talus slopes, Valais, Swiss Alps. Geomorphology 132, 208-221. doi: 10.1016/j.geomorph. 2011.05.010

Scherler, M., Schneider, S., Hoelzle, M., and Hauck, C. (2014). A two-sided approach to estimate heat transfer processes within the active layer of the Murtèl-Corvatsch rock glacier. Earth Surf. Dyn. 2, 141-154. doi: 10.5194/esurf2-141-2014

Shewchuk, J. R. (1996). “Triangle: engineering a 2D quality mesh generator and delaunay triangulator," in Applied Computational Geometry Towards Geometric Engineering, eds C. L. Ming and M. Dinesh (Berlin: Springer), 203-222. doi: $10.1007 / \mathrm{bfb} 0014497$

Sollid, J. L., Holmlund, P., Isaksen, K., and Harris, C. (2000). Deep permafrost boreholes in western Svalbard, northern Sweden and southern Norway. Norsk Geografisk Tidsskrift 54, 186-191. doi: 10.1080/002919500448567

Steiger, C., Etzelmüller, B., Westermann, S., and Myhra, K. S. (2016). Modelling the permafrost distribution in steep rock walls in Norway. Norwegian J. Geol. 96, 329-341. doi: 10.17850/njg96-4-04

Tveito, O. (2000). Nordic Temperature Maps. Oslo: Norwegian Meteorological Institute.

Walder, J., and Hallet, B. (1985). A theoretical model of the fracture of rock during freezing. Geol. Soc. Am. Bull. 96, 336-346. doi: 10.1130/0016-7606

Westermann, S., Schuler, T. V., Gisnås, K., and Etzelmüller, B. (2013). Transient thermal modeling of permafrost conditions in Southern Norway. Cryosphere 7, 719-739. doi: 10.5194/tc-7-719-2013

Wicky, J., and Hauck, C. (2017). Numerical modelling of convective heat transport by air flow in permafrost talus slopes. Cryosphere 11, 1311-1325. doi: 10.5194/ tc-11-1311-2017

Conflict of Interest Statement: The authors declare that the research was conducted in the absence of any commercial or financial relationships that could be construed as a potential conflict of interest.

Copyright (c) 2019 Myhra, Westermann and Etzelmüller. This is an open-access article distributed under the terms of the Creative Commons Attribution License (CC BY). The use, distribution or reproduction in other forums is permitted, provided the original author(s) and the copyright owner(s) are credited and that the original publication in this journal is cited, in accordance with accepted academic practice. No use, distribution or reproduction is permitted which does not comply with these terms. 